\title{
Energy Sustainability and Its Impacts on Croatian Tourism
}

Marinela Krstinić Nižić

University of Rijeka, Faculty of Tourism and Hospitality Management in Opatija, Croatia

marikn@fthm.hr

\section{Zvonimira Šverko Grdić}

University of Rijeka, Faculty of Tourism and Hospitality Management in Opatija, Croatia

zgrdic@fthm.hr

\section{Renata Endres}

University of Rijeka, Faculty of Tourism and Hospitality

Management in Opatija, Croatia

renatad@fthm.hr
CroEconSur

Vol. 19

No. 2

December 2017

pp. 83-104

Received: February 10, 2017

Accepted: July 24, 2017

Review Article

doi:10.15179/ces.19.2.3

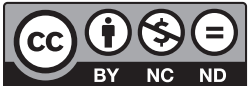

\section{Abstract}

Energy efficiency, renewable energy sources, and environmental protection projects play a pivotal role in tourism. The World Tourism Organization (UNWTO) addresses resource management and energy use as one of the major issues. The main goal of the paper is to present the economic-financial analysis and the assessment of investment projects in the construction of a conventional mid-size hotel using fossil fuels and a mid-size hotel based on sustainable principles and renewable energy sources. Comparative analysis of conventional and energyefficient hotels is used to calculate the key financial indicators in decisionmaking. Case study shows that the introduction of renewable energy sources meets the needs of modern guests and increases the hotel's competitiveness, while the effects of energy sustainability reflect on the environment and reduced $\mathrm{CO}_{2}$ emissions. Based on the results, the paper suggests measures for improving 
energy sustainability in hotels and other tourism facilities. The paper is intended for those who deal with theoretical and practical issues of energy sustainability in tourism, tourism certificates, renewable energy sources and investment costs - scientists, researchers, $\mathrm{PhD}$ candidates and students as a basis for further comparative studies and benchmarking. It can also be useful for a considerably wider circle of users-managers at all levels and other business decision makers, as well as proprietors, investors, and creditors.

Keywords: energy sustainability, hotel industry, ecological certificate, $\mathrm{CO}_{2}$ emission, investment costs, energy efficiency measures

JEL classification: O13, P28, Q01, Q50, Z32

\section{Introduction'}

Tourism is considered to be not only one of the fastest growing economic sectors, but also one of the key drivers of socio-economic progress of the country (Snowden Duffield, 1982). According to the Croatian National Bank (CNB) (CNB, 2016), the revenues from travel and tourism in the period July-September 2016 amounted up to EUR 5.46 billion, which is EUR 450.2 million, or nearly nine percent more compared to the third quarter of 2015. In Croatia, tourism is one of the main sources of income, generating 18 percent of direct contribution to the GDP and is therefore the most vital economic activity (IZTZG, 2014). This implies a significant potential for growth, development and a stronger involvement of all relevant stakeholders in Croatian economy (Blažević, 2007). However, tourism is susceptible to various risks such as geopolitical instability, climate change and other environmental problems. There is a growing interest of business entities, including hotels, to solve the problem of using fossil energy sources and to meet current environmental standards. In its document Agenda 21 for the Tourism and Travel Industry, the World Tourism Organization (UNWTO) addresses resource management and energy use as one of the major issues (Becken, 1 This paper has been financially supported by the University of Rijeka, for the project ZP UNIRI 4/16. 
2013). The goal of Agenda 21 is to assist tourism authorities-ministries, tourist organizations, business associations, hotels, and businesses in the tourism sector realize their potentials, achieve sustainable development, and a higher level of energy efficiency (UNEP and ICLEI, 2003). Hotel energy efficiency constitutes a vital part of the eco-efficiency and tourism operations (Tsagarakis et al., 2011). The implementation of green concepts in the construction and operation is part of the Croatian Tourism Development Strategy until 2020 (MINT, 2013), whereby green hospitality represents a movement that has been recognized by the environmentally-conscious guests (UNEP and UNWTO, 2012), as well as hotel managers (Baker, Davis and Weaver, 2014; Manan et al., 2010). The goal of the paper is to present the economic-financial analysis and the assessment of investment projects in the construction of a conventional mid-size hotel using fossil fuels and a mid-size hotel based on sustainable principles and renewable energy sources. The paper is structured as follows. The following section provides the conceptual framework of the analysis. Section three explains the methodology and hotel characteristics used as the research sample. Using the example of two average hotels in Croatia, a preliminary financial analysis and a business plan were carried out to calculate not only the key financial indicators, but also the reduction of $\mathrm{CO}_{2}$ emissions. Section four proposes new energy measures needed for improving energy sustainability in hotels. Section five provides the conclusion.

\section{Literature Review}

Many foreign authors (Chan, 2008; Chan, 2012; Kirk, 1995; Marunda, Judias Sai and Muchenje, 2013), as well as local authors (Petrić and Pranić, 2009, Radić Lakoš, Sladoljev and Goleš, 2009) agree that those hotels, which are a part of large hotel chains, apply energy efficiency and sustainable development measures more quickly and more often. The reason for this, other than simple rationalization measures, is that most activities require a significant initial investment. Although the return on this investment is relatively quick, the hotels that operate without a secure and stable financial and managerial support find such an investment 
more difficult to afford. Hotel facilities are great consumers of energy, which implies high energy costs (Farrou, Kolokotroni and Santamouris, 2012). However, energy costs can be effectively controlled, which in turn affects the financial results and increases profits (Santamouris et al., 1996). Although there are many investment studies and energy efficiency projects which aim to reduce energy costs (HES, 2011), they should be approached and applied selectively, without decreasing the level of service quality and guest satisfaction. One way to encourage energy efficiency and the rational use of energy in hotels is to promote guests' environmental awareness. The most flexible, practical and cost-effective solution for improving energy efficiency is the use of renewable energy sources. In order to develop a sustainable and renewable energy system, it is important to encourage the use of renewable energy sources for heating and cooling. This can be achieved through the promotion of individual systems that use renewable energy sources (RES) (or electricity from RES) or by using centralized heating systems for district heating and cooling using renewable energy sources (or electricity from RES). One prerequisite for the achievement of this objective is an increase in energy efficiency, i.e. reducing the need for heating and cooling technologies (Enea, 2010). This, in turn, requires specific legislative measures at the state level, as well as support mechanisms and subsidies which would motivate the hoteliers to implement RES more often. One of the mechanisms of achieving that would involve each of the regional energy agencies operating in Croatia informing the hotel owners and managers about the tenders published by the Environmental Protection and Energy Efficiency Fund, as well as applications for various EU funds (EC, 2014). One of the motives behind such a mechanism could include environmentally-conscious guests who are increasingly interested in accommodation that meets the environmental standards and who are willing to pay more for a green service (Kostakis and Sardianou, 2012). In addition to energy efficiency measures, the implementation of green certificates can also be one of the more important goals for policy-makers (Stefanica, 2013). A number of hotels in Croatia base their operation on green hospitality principles. The analysis of the 2017 situation reveals that Croatia currently has 41 hotels 
with the Sustainable Hotel Certificate by UPUHH, awarded by the Association of Employers in Croatian Hospitality (UPUHH) (UPUHH, 2016) for the period from 2014 to 2016. The certificate guarantees that the facility follows global trends in sustainable business, such as: successful sustainability management in daily hotel business, environmental protection, continuous environmental protection awareness raising, energy efficiency, staff training, energy and water saving, sustainable procurement, sales, marketing and PR, and the control of $\mathrm{CO}_{2}$ emissions. Figure 1 shows the current list of certified eco-friendly hotels in Croatia. The competitiveness of firms (hotels) depends on internal efforts, but also on a number of external factors such as the overall perception of producers coming from a region or city (Stojčić, Bačić and Aralica, 2016).

Figure 1: Map of Certified Eco-friendly Hotels by Destination in Croatia

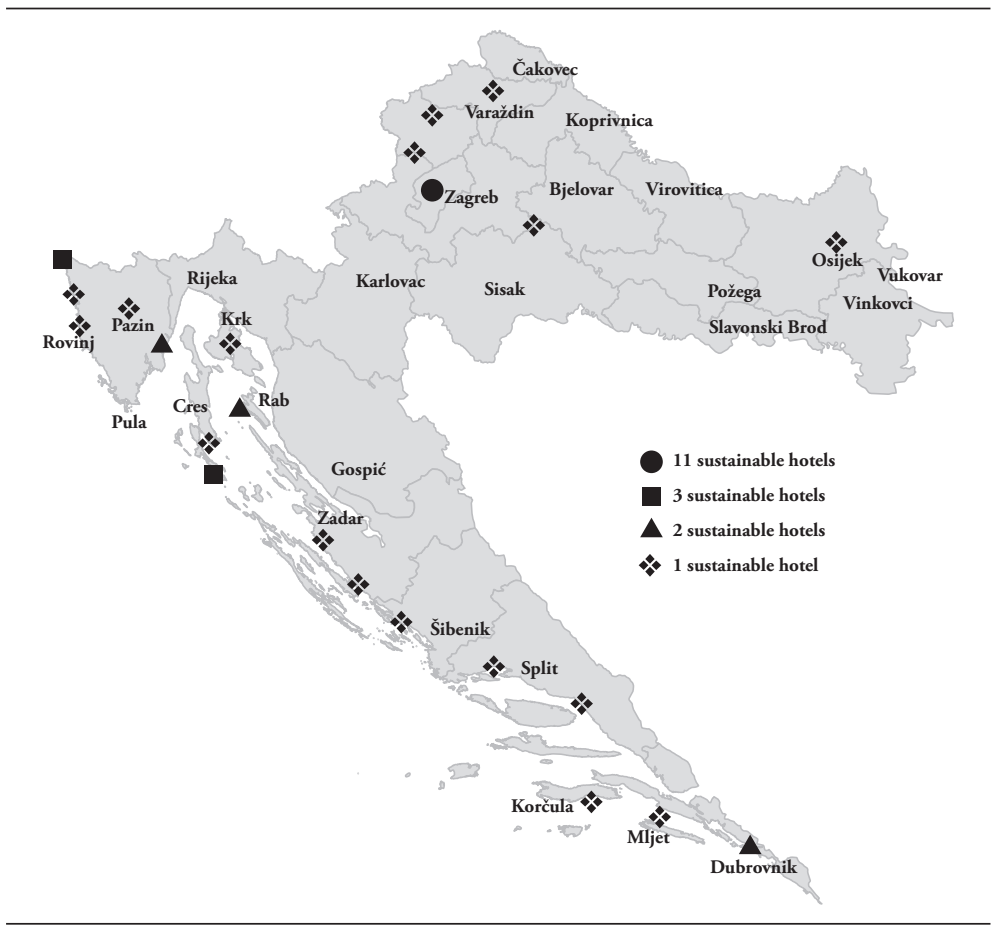

Source: Authors' analysis of UPUHH Zagreb data. 
One reason for concern is the fact that out of 200 UPUHH members, which account for about 80 percent of the total Croatian hotel industry, only 41 have been rewarded the Sustainable Hotel Certificate. However, the plan is that by the end of 2018, other hotels also adopt the concept of a green business, and that new professional associations (from camping, nautical and other segments of tourism) join the project. The costs of this project are covered by the UPUHH and cofinanced by the Ministry of Tourism and other partners. The strategic goal of the project is in line with the goals of the Croatian Tourism Development Strategy until 2020, which are based on the introduction of green business practices and which imply a synergy of economic benefits, concerns for the environment in its broadest sense, and social inclusion in a wider community (IZTZG, 2016; MINT, 2013), all in accordance with the principles of sustainable development and energy efficiency.

\section{Methodology and Results}

This section provides the research methodology and a description of survey data analysis. Information needed for the cost-effectiveness analysis of the construction of a conventional hotel and an energy-efficient hotel has been collected on the market, and refers to the prices of accommodation, food and drinks, energy prices, construction costs, employee costs etc. Research data was obtained by interviewing the members of the controlling services and human resources in similar hotel companies in the Primorje-Gorski Kotar County and Istria. Basic technical parameters and legal and legislative regulations of the Republic of Croatia were also used in the research. The final sources of data are the assumptions and forecasts that, in the absence of exact data, have to be applied in certain cases. All of the abovementioned parameters were used in the presented model of the conventional and energy-sustainable hotel. The paper presents not only the assessment of the financial elements, but also the assessment of the social benefits of the two hotels and an estimate of $\mathrm{CO}_{2}$ emission reduction 
for both hotels. It should be emphasized that the 15-year projection (until 2031) was made on the following bases:

- Both hotels are situated on the Croatian coast and are categorized as fourstar hotels.

- Both hotels have 50 double rooms, i.e. 100 accommodation units.

- Both hotels have one pool, a restaurant and a congress hall; a total area of $3000 \mathrm{~m}^{2}$; the size of each room is $26 \mathrm{~m}^{2}$.

- Both hotels have 41 employees.

- The average room price is EUR 195.

- During the first three years, both hotels increased their revenues by six percent per year. In years four through seven, the annual increase was seven percent per year, followed by six percent per year until the end of the period observed. The pace of the revenue increase is based on the UNWTO tourists' arrival forecasts for the Mediterranean and on conversations with workers in the tourism sector who deal with tourism revenue calculations in Croatia. The forecast of the pace of revenue increase is held the same for both hotels in order to avoid biasing the revenue-based financial results of one of the hotels. Financial revenues in both hotels increase by 0.2 percent per year. Those revenues are not large amounts and therefore their increase does not have a significant share in total revenues.

- Expenditures include material costs that increase by two percent per year in both hotels and other expenses that increase by 0.5 percent annually. In addition, depreciation rate is calculated based on the Croatian accounting regulations, while financial expenses are calculated based on a five percent interest rate. Income tax, which is currently 20 percent, is also calculated according to the Croatian accounting regulations. Revenue increases are based on the hotel sector forecasts for future periods. 
- Costs for employees in a classic hotel are somewhat lower at the beginning, while increasing at an average two percent annual rate. In order to maintain the whole system, the energy-efficient hotel needs to hire experts on energy efficiency, and therefore, the starting costs for employees are somewhat higher while continuing to grow at a three percent yearly rate. Due to the fact that other costs in an energy-efficient hotel are lower than in a conventional hotel, it was possible to forecast a higher wage increase.

- Parameters needed to analyze hotels are not based on any particular hotel operation, but rather on common characteristics across a range of existing hotels and on information gathered through interviews with hotel experts.

- The conventional hotel uses fuel oil, while the energy-efficient hotel uses solar energy.

The parameters required for the analysis of the conventional and energysustainable hotel models do not refer to any particular hotel, but are based on certain prominent characteristics of the existing hotel facilities on the Croatian coast. The coastal part of Croatia is used for case analysis because real estate prices are higher than in the continental part. The tables below show the basic business elements of both models. 


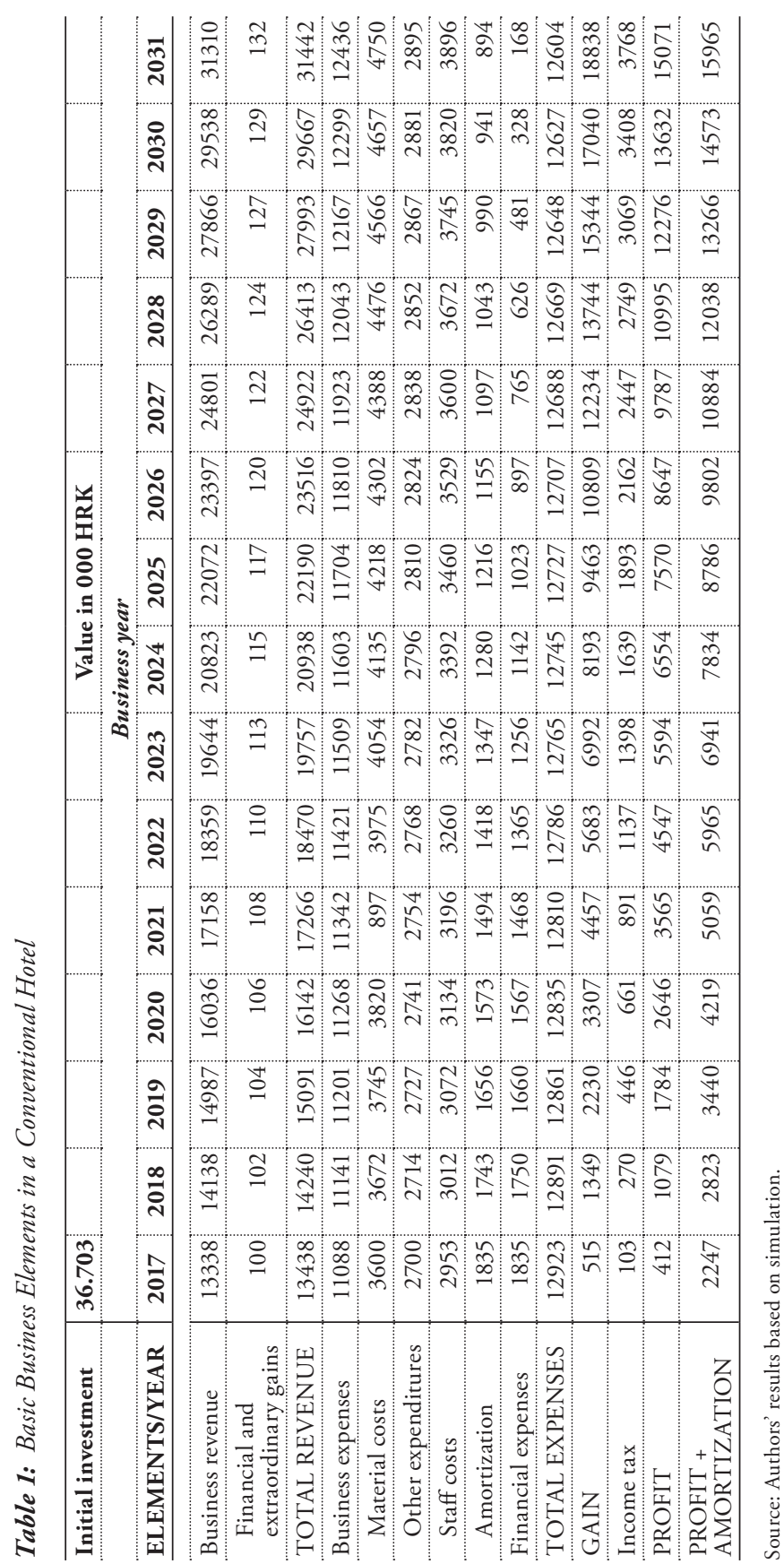


The projection is made based on the abovementioned input parameters, with an investment made in the construction of a conventional hotel in value of HRK 36.7 million.

Apart from the financial indicators, the environmental features of the hotel itself (i.e., $\mathrm{CO}_{2}$ emissions) are also shown. Fuel oil consumption and higher levels of greenhouse gas emissions are to be expected in a conventional hotel, as shown in the following table.

Table 2: $\mathrm{CO}_{2}$ Emissions by Energy Source Relating to the Consumption in a Conventional Hotel

\begin{tabular}{l|c}
\hline Description & Conventional hotel \\
\hline Greenhouse gas emission: & $2.605 \mathrm{~kg} / \mathrm{year}$ \\
\hline - Water consumption & $128.471 \mathrm{~kg} / \mathrm{year}$ \\
• Fuel oil consumption & $227.370 \mathrm{~kg} / \mathrm{year}$ \\
• Electrical energy & \\
\hline Electricity produced by photovoltaic collectors & $357.906 \mathrm{~kg} / \mathrm{year}$ \\
\hline TOTAL & $\mathrm{HRK} 18,00$ \\
\hline Fee per 1 t of $\mathrm{CO}_{2}$ emitted & $6.444,00$ \\
\hline Annual fee in $\mathrm{HRK}$ & \\
\hline
\end{tabular}

Source: Authors' results based on simulation.

An average conventional hotel emits around 358000 kilograms of $\mathrm{CO}_{2}$ into the atmosphere every year. Other than the financial data obtained, no additional economic benefits have been taken into account in the analysis, such as indirect employment, regional economic growth, improved infrastructure and competitiveness, labor and population mobility, support to related industries and businesses etc. 


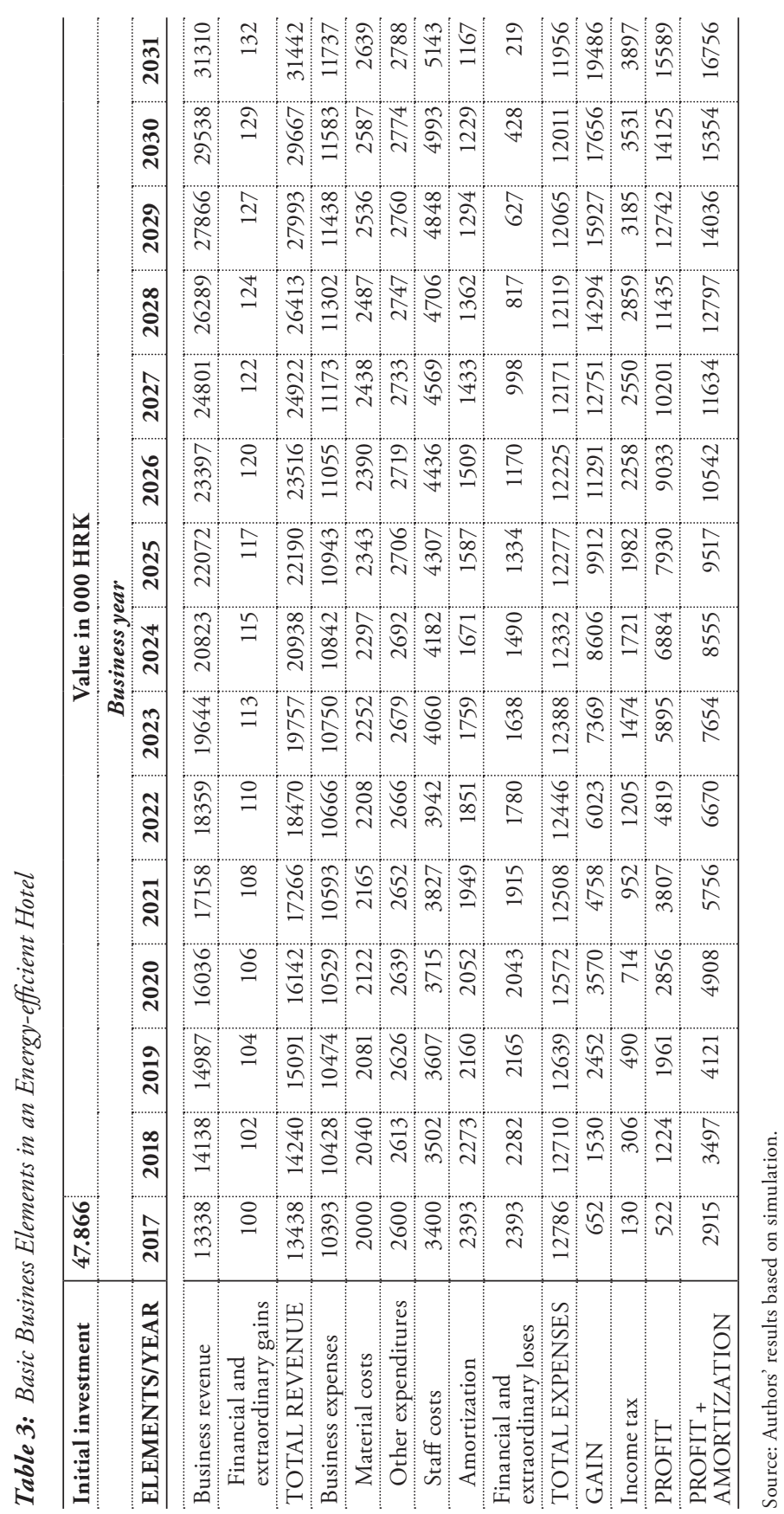


Based on literature research, it is estimated that the construction costs will be increased by 30 percent for an energy-efficient hotel model compared to the conventional hotel (Hrs Borković, Kulišić and Zidar, 2008). Investments in the construction of this hotel amount up to HRK 47.8 million.

An energy-efficient, sustainable hotel uses solar energy and thus emits less $\mathrm{CO}_{2}$ than the conventional hotel, as can be seen in the following table.

Table 4: $\mathrm{CO}_{2}$ Emissions by Energy Source Relating to the Consumption in a Sustainable Hotel

\begin{tabular}{|c|c|}
\hline Description & Sustainable hotel \\
\hline \multicolumn{2}{|l|}{ Greenhouse gas emission: } \\
\hline - Water consumption & $1.605 \mathrm{~kg} /$ year \\
\hline - Fuel oil consumption & $0,00 \mathrm{~kg} /$ year \\
\hline - Electrical energy & $136.446 \mathrm{~kg} /$ year \\
\hline Electricity produced by photovoltaic collectors & $-29.812 \mathrm{~kg} /$ year \\
\hline TOTAL & $108.239 \mathrm{~kg} /$ year \\
\hline Fee per $1 \mathrm{t}$ of $\mathrm{CO}_{2}$ emitted & HRK 18,00 \\
\hline Annual fee in HRK & 1.944 \\
\hline
\end{tabular}

Source: Authors' results based on simulation.

The energy-efficient, sustainable hotel annually emits around 108,000 kilograms of $\mathrm{CO}_{2}$ into the atmosphere, which is significantly less than the conventional hotel. Just like the conventional hotel, the energy-efficient hotel also brings economic and social benefits, but the importance of the realization of such investments is reflected in its environmental benefits, as well as the creation of a new image of an environmentally-friendly business on the market. By using renewable energy sources, this hotel is involved in environmental protection and climate change in terms of reducing the amount of $\mathrm{CO}_{2}$ emissions and contributing to the energy supply security. The concluding assessment of both projects is presented in the following table. 
Table 5: A Comparative Analysis and Concluding Assessment of the Conventional and Sustainable Hotel

\begin{tabular}{l|c:c}
\hline Description & Conventional hotel & Sustainable hotel \\
\hline IRR & $10,81 \%$ & $8,36 \%$ \\
\hline Payback period & 15 years & 18 years \\
\hline NPV (with discount rate of 5\%) in 000 HRK & 24.439 & 16.754 \\
\hline
\end{tabular}

Notes: IRR - Internal Rate of Return; NPV - Net Present Value.

Source: Authors' results based on simulation.

The discount rate in economic analysis tends to reflect the public view of the ways in which future benefits and expenditures should be valued in relation to current benefits and expenditures. It may differ from the financial yield rate when the capital market is imperfect (Blažević and Krstinić Nižić, 2011). This research takes a five percent discount rate, while for future research, a lower discount rate is recommended. Although the construction of a conventional hotel is more acceptable based on economic rating, this hotel type is not sufficiently aligned with the guests' environmental requirements and does not use alternative sources of energy, which is the primary goal of the European Union energy policy. The World Tourism Organization predicts an increase in the number of eco-tourists and Croatian tourism will also need to adjust to this trend. This is exactly what a sustainable hotel strives for, oriented toward the future and the promotion and implementation of renewable energy sources. The 18-year return on investment period for an energy-efficient hotel should not play a crucial role for the investors in their consideration of a responsible business and greater competitiveness not only for the hotel, but also for the Croatian tourism in general. Similarly, the construction of such hotels results in the reduction of $\mathrm{CO}_{2}$ emissions, which is in line with the goals set out during the $21^{\text {st }}$ United Nations Framework Convention on Climate Change (UNFCCC) (Conference of the Parties - COP 21) Conference held in Paris in December 2015. The conference adopted a new global climate change agreement which includes an action plan to keep global warming 'to well below two degrees Celsius' (UNFCCC, 2015). 


\section{Measures and Recommendations for Energy Sustainability Improvement of Croatian Tourism}

Croatian energy statistics and state policy measures have not yet recognized the problem of power consumption in tourism facilities, camps, hotels, and apartments. Unfortunately, there was also no encouragement for the energy renovation of those facilities, even though the energy and financial effects that could be achieved by energy renovation are substantial. Therefore, the following table provides a number of proposed measures for improving energy sustainability in tourism facilities.

Table 6: Proposed Measures for the Improvement of Energy Sustainability in Hotels and Other Tourism Facilities

\begin{tabular}{|c|c|}
\hline $\begin{array}{l}\text { Measure } 1-\text { The } \\
\text { use of solar thermal } \\
\text { heating systems for } \\
\text { domestic hot water }\end{array}$ & $\begin{array}{l}\text { This measure aims to eliminate the use of electricity and fossil fuels for heating } \\
\text { and to promote the use of Sun's energy whenever possible. Each tourism } \\
\text { facility should at least consider heating domestic hot water using the Sun. In } \\
\text { order for these procedures to become used on a large scale, it is necessary to } \\
\text { develop various analyses and implementation projects, which would allow } \\
\text { better support and maintenance, and remove barriers to implementation. }\end{array}$ \\
\hline $\begin{array}{l}\text { Measure } 2- \\
\text { Increasing the } \\
\text { efficiency of cooling } \\
\text { systems in hotels } \\
\text { and other tourism } \\
\text { facilities }\end{array}$ & $\begin{array}{l}\text { This measure aims to encourage a wider use of energy-efficient cooling systems } \\
\text { in hotels. This refers to the use of a centralized cooling system in larger hotels, } \\
\text { the use of heat pumps, and utilizing the environment for thermal energy } \\
\text { storage (sea water). In addition to energy savings, this also results in peak load } \\
\text { reductions. Furthermore, this measure also allows a centralized heating system } \\
\text { that ensures a longer season during the winter. }\end{array}$ \\
\hline $\begin{array}{l}\text { Measure } 3- \\
\text { Implementation of } \\
\text { green certificates }\end{array}$ & $\begin{array}{l}\text { Apart from the standard norms such as ISO 14001, facilities in tourism are } \\
\text { encouraged to implement ISO } 50001 \text { (for systematic energy management), } \\
\text { as well as other environmental certificates that not only contribute to the } \\
\text { image of the facility but also oblige the management to comply with a set of } \\
\text { environmental criteria. }\end{array}$ \\
\hline $\begin{array}{l}\text { Purpose and } \\
\text { application }\end{array}$ & $\begin{array}{l}\text { Measures of energy sustainability are primarily intended for managers and } \\
\text { hotel owners. }\end{array}$ \\
\hline Implementation & $\begin{array}{l}\text { The Ministry of Economy, Entrepreneurship and Crafts, the Ministry of } \\
\text { Environmental Protection and Energy, and the Ministry of Tourism should all } \\
\text { include these measures in their programs and promote them among the owners } \\
\text { of hotels and other tourism facilities. }\end{array}$ \\
\hline Financing & $\begin{array}{l}\text { - The Environmental Protection and Energy Efficiency Fund (FZOEU) } \\
\text { - Croatian Bank for Reconstruction and Development (HBOR) } \\
\text { - Croatian Agency for Small Business and Investments (HAMAG INVEST) } \\
\text { - The European Investment Bank (EIB) } \\
\text { - The European Bank for Reconstruction and Development (EBRD) } \\
\text { - The European Energy Efficiency Fund (EEEF) } \\
\text { - CroPSSF Sustainable Energy (a line of credit developed in cooperation } \\
\text { between the EBRD and the EU). }\end{array}$ \\
\hline
\end{tabular}

Source: Authors' research. 
The Republic of Croatia has recognized the importance of financial support for environmental protection, energy efficiency and renewable energy projects by setting up special programs, funds and credit lines for the entrepreneurial sector. National institutions such as the Environmental Protection and Energy Efficiency Fund and the Croatian Bank for Reconstruction and Development, which are engaged in the achievement of energy goals, are also supported by the European development banks such as the European Investment Bank and the European Bank for Reconstruction and Development. This paper lists the currently available financial sources in the Republic of Croatia, while a deeper analysis is recommended for further research. The Croatian tax system has no special fiscal instruments which would encourage the procurement or investment in equipment for an increase in energy efficiency. In the European Union, 14 member states have so far introduced some type of special fiscal measures to boost energy efficiency investments (MGIPU, 2015). These mostly refer to various types of tax exemption aimed at specific consumer groups (citizens or the entrepreneurial sector), while a smaller number of countries have also introduced a lower value added tax (VAT) rates for energy-efficient equipment. One of the advantages of introducing a lower VAT rate is that it refers to all consumer groups. However, it also brings additional complications into the tax system and makes it administratively more expensive to implement. Nevertheless, experiences from other countries show that lower tax rates and tax incentives have a significant impact on increasing investments in energy-efficient equipment and represent an excellent complementary instrument, along with preferential credit lines and subsidies for entrepreneurs. It is important to note that the limitations defined by the European Commission regarding the amount of state aid also include tax incentives.

The aim of the recommendations that are presented below is to encourage researchers, hoteliers, managers, and citizens to implement energy efficiency measures in their operations as much as possible, and to be guided by best practices of investment in green technologies and renewable energy sources 
(Zografakis and Sifaki, 2010). At the national level, it is necessary to implement various national policies to increase energy efficiency (MINGO, 2009; MINGO, 2014). Likewise, it is equally important to systematically improve and ensure the implementation of energy-efficiency measures and policies as a strong incentive to reduce energy dependence. Reducing energy dependence also leads to reduced energy imports, a positive balance of payments, and a parallel increase of domestic production through local jobs and the development of renewable energy sources (Krstinić Nižić, Šverko Grdić and Hustić, 2016).

\section{Conclusion}

European hotels innovate their products and services and introduce green measures into their business practice. Their businesses become recognizable on the market by various environmental certificates (e.g., Green Key, Sustainable Hotels etc.). Tourism in Croatia has not yet sufficiently recognized the quality and importance of these and other environmental certificates.

Therefore, these models of conventional and energy-efficient hotels can help future researchers, as well as investors, in deciding on their business model. Although it is evident that the return on investment period is shorter for the conventional hotel and that the internal rate of return and net present value are higher, the evaluation process needs to analyze not only market efficiency, but also the socio-economic efficiency. The proposed model of a sustainable hotel can become the basis for hotel industry trends in Croatian tourism. An energy-efficient hotel can prove that an advanced sustainability strategy does not exclude economic success. Such a hotel follows environmental guidelines, providing future guests with safe, energy-efficient accommodation and raising the competitiveness of Croatian tourism. Social benefits, which are defined as positive effects influencing the process of socio-economic development, are also immeasurable benefits not marketed and to which it is difficult or impossible 
to attribute monetary value (quality of stay in a destination, air purity, energy supply, security etc.).

Therefore, the authors recommend involving both the staff and the guests in energy sustainability processes from the very beginning in order to increase their awareness of energy saving. The analyzed and estimated $\mathrm{CO}_{2}$ emissions in hotels stress the importance of removing the obstacles to the implementation of energyefficiency measures in existing tourism facilities, as well as the importance of introducing renewable energy sources and energy-efficient technologies. It can be concluded that, despite the fact that the conventional hotel has better economic results, this should not be the sole indicator for the decision to build a certain type of hotel.

The paper highlights undeniable opportunities and benefits of energy sustainability. Furthermore, it stresses the necessity of a new approach to future tourism development in this area, which must necessarily be based on energy sustainability and sustainable development. The authors put forward the proposed measures and activities to be taken in order to successfully integrate Croatian tourism in the European market, and to ensure a long-term, sustainable development of Croatian tourism. 


\section{Literature}

Association of Employers in Croatian Hospitality (UPUHH), 2016, Sustainable Hotels Certificate, http://www.upuhh.hr/en/projekti/green-sustainable-business/ sustainable-hotels/item/28-dodjela-sustainable-hotel-certificate-by-upuhh (accessed October 18, 2017).

Baker, A. Melissa, Erica A. Davis and Pamela A. Weaver, 2014, "Ecofriendly Attitudes, Barriers to Participation, and Differences in Behavior at Green Hotels", Cornell Hospitality Quarterly, 55(1), pp. 89-99. https://doi. org/10.1177/1938965513504483

Becken, Susanne, 2013, "A Review of Tourism and Climate Change as an Evolving Knowledge Domain”, Tourism Management Perspectives, 6, pp. 53-62. https://doi.org/10.1016/j.tmp.2012.11.006

Blažević, Branko, 2007, Turizam u gospodarskom sustavu, Opatija: University of Rijeka, Faculty of Tourism and Hospitality Industry.

Blažević, Branko and Marinela Krstinić Nižić, 2011, "Ocjena investicijskog modela primjenom diskrecijske diskontne stope - slučaj obnovljivih izvora energije u turizmu", Ekonomski pregled (Economic Review), Zagreb: Croatian Economic Association - The Institute of Economics, Zagreb, 11, pp. 636-661.

Chan, Eric Siu Wa, 2008, "Barriers to EMS in the Hotel Industry", International Journal of Hospitality Management, 27(2), pp. 187-196.

Chan, Wilco, 2012, "Energy Benchmarking in Support of Low Carbon Hotels: Developments, Challenges, and Approaches in China”, International Journal of Hospitality Management, 3, pp. 1130-1142. https://doi.org/10.1016/j. ijhm.2012.02.001

Croatian National Bank (CNB), 2016, Makroekonomska kretanja i prognoze, Zagreb: Croatian National Bank, https://www.hnb.hr/documents/20182/ 1199956/hMKP_01.pdf/2c76ca58-0c4a-4423-b00b-a131bcdf06e8 (accessed January 15,2017$)$. 
Enea, Constanța, 2010, "Increase Efficiency Ecological - Objective of Tourism Policy - An Integral Part of National and World Sustainable Development", Journal of Tourism, 9, pp. 49-55.

European Commission (EC), 2014, Commission Decision on the Annual Work Programme for 2015 in the Field of Energy, Brussels: European Commission, https://ec.europa.eu/energy/sites/ener/files/documents/c_2014_7588_f1_ commission_decision_v3_p1_785382_en.pdf (accessed December 20, 2016).

Farrou, Ifigenia, Maria Kolokotroni and Mat Santamouris, 2012, "A Method for Energy Classification of Hotels: A Case-Study of Greece”, Energy and Buildings, 55, pp. 553-562. https://doi.org/10.1016/j.enbuild.2012.08.010

Hotel Energy Solutions (HES), 2011, Best Practices Guide: Successful Energy Efficiency Technologies Integration in SME Hotels, Hotel Energy Solutions project publications, Spain: World Tourism Organization (UNWTO), http://hes.unwto.org/sites/all/files/docpdf/ bestpracticesguidesuccessfuleetintegrationinsmehotelsaugustfinalversion2.pdf (accessed November 20, 2016).

Hrs Borković, Željka, Biljana Kulišić and Margareta Zidar, 2008, “Energy Audit - Method for Energy Conservation in Hotels, Renewable Energy Sources in the Development of the Hotel and Tourism Industry", paper presented at the conference "Tourism and Hospitality Industry" organized by the Faculty of Tourism and Hospitality Management, Opatija, May 7-9.

Kirk, David, 1995, "Environmental Management in Hotels", International Journal of Contemporary Hospitality Management, 7, pp. 3-8. https://doi. org/10.1108/09596119510095325

Kostakis, Ioannis and Eleni Sardianou, 2012, "Which Factors Affect the Willingness of Tourists to Pay for Renewable Energy?", Renewable Energy, 38(1), pp. 169-172. https://doi.org/10.1016/j.renene.2011.07.022 
Krstinić Nižić, Marinela, Zvonimira Šverko Grdić and Andreja Hustić, 2016, "The Importance of Energy for the Tourism Sector", Academica Turistica, Tourism and Innovation Journal, 9(2), pp. 77-83.

Manan, Zainuddin Abdul, Lim Jeng Shiun, Sharifah Rafidah Wan Alwi, Haslenda Hashim, K. S. Kannan, Norhasliza Mokhtbar and Ahmad Zairin Ismail, 2010, "Energy Efficiency Award System in Malaysia for Energy Sustainability", Renewable and Sustainable Energy Reviews, 14(8), pp. 22792289. https://doi.org/10.1016/j.rser.2010.04.013

Marunda, Edmond, Peter Judias Sai and Blessing Muchenje, 2013, "Challenges Facing Use of Energy in the Tourism and Hospitality Industry in Zimbabwe and Policies that Can Promote the Sustainable Use of Renewable Energy and Tourism Development", International Journal of Development and Sustainability, 2, pp. 472-484.

Ministry of Construction and Physical Planning (MGIPU), 2015, Program energetske obnove komercijalnih nestambenih zgrada za razdoblje 2014.-2020. s detaljnim planom energetske obnove komercijalnih nestambenih zgrada za razdoblje 2014.-2016., Zagreb: Ministry of Construction and Physical Planning (MGIPU), http://cei.hr/upload/2014/08/program_eo_kz_2014-2020_53fb246f3ec10.pdf (accessed June 9, 2017).

Ministry of Economy, Entrepreneurship and Crafts (MINGO), 2009, Strategija energetskog razvoja Republike Hrvatske (Croatian Energy Strategy), Zagreb: Ministry of Economy, Entrepreneurship and Crafts (MINGO), https://narodnenovine.nn.hr/clanci/sluzbeni/2009_10_130_3192.html (accessed January 12, 2017).

Ministry of Economy, Entrepreneurship and Crafts (MINGO), 2014, Treći nacionalni akcijski plan energetske učinkovitosti za razdoblje 2014.-2016. (Third National Energy Efficiency Action Plan for the Period 2014-2016), Zagreb: Ministry of Economy, Entrepreneurship and Crafts (MINGO), http://www. mingo.hr/public/3\%20Nacionalni_akcijski_plan.pdf (accessed November 18, 2017). 
Ministry of Tourism (MINT), 2013, Strategija razvoja turizma Republike Hrvatske do 2020. godine (Croatian Tourism Development Strategy until 2020), Zagreb: Ministry of Tourism (MINT), http://www.mint.hr/UserDocsImages/ Strategija-turizam-2020-editfinal.pdf (accessed October 18, 2017).

Petrić, Lidija and Ljudevit Pranić, 2009, “Croatian Hoteliers' Attitudes Towards Environmental Management", paper presented at the international conference "Challenges of Europe: Financial Crisis and Climate Change" organized by the Faculty of Economics Split, Split, May 21-23.

Radić Lakoš, Tanja, Jasmina Sladoljev and Divna Goleš, 2009, "Norma ISO 14000 u hrvatskim hotelima” u Marko Bešker and Miroslav Drljača, eds., Kvaliteta i procesno upravljanje, pp. 1-9, Zagreb: Croatian Quality Managers Society, https://bib.irb.hr/datoteka/582662.Norma_ISO_14000_u_hrvatskim_ hotelima.pdf (accessed January 10, 2017).

Santamouris, Matheos, Constantinos Balaras, Elena Dascalaki, Athanassios A. Argiriou and Athina Gaglia, 1996, "Energy Conservation and Retrofitting Potential in Hellenic Hotels", Energy and Buildings, 24(1), pp. 65-75. https://doi. org/10.1016/0378-7788(95)00963-9

Snowden Duffield, Brian, 1982, "Tourism: The Measurement of Economic and Social Impact", Tourism Management, 3(4), pp. 248-255. https://doi. org/10.1016/0261-5177(82)90046-2

Stefanica, Mirela, 2013, "Ecological Certification and Labelling of Tourist Services”, CES Working Paper, 5(4), pp. 615-625, December, Iasi: Centre for European Studies (CES).

Stojčić Nebojša, Katarina Bačić and Zoran Aralica, 2016, "Is Creative Economy in Croatia a Myth or Reality? Some Evidence on the Impact of Creativity on Regional Economic Growth”, Croatian Economic Survey, 18(2), pp. 113-138. https://doi.org/10.15179/ces.18.2.4 
The Institute for Tourism (IZTZG), 2014, Satelitski račun turizma RH za 2011. godinu i izračun neizravnih ukupnih učinaka turizma u $R H$, Zagreb: The Institute for Tourism.

The Institute for Tourism (IZTZG), 2016, Akcijski plan razvoja zelenog turizma, Zagreb:TheInstitutefor Tourism, http://www.mint.hr/UserDocsImages/160715_ AP_Zelenog_t.pdf (accessed October 15, 2016).

The $21^{\text {st }}$ United Nations Framework Convention on Climate Change (UNFCCC) (Conference of the Parties - COP 21) Conference, 2015, Report of the Conference of the Parties on its Twenty-first Session, Paris: United Nation Framework Convention on Climate Change (UNFCCC), http://unfccc.int/ resource/docs/2015/cop21/eng/10.pdf (accessed June 10, 2017).

Tsagarakis, P. Konstantinos, Fanouria Bounialetou, Konstantinos Gillas, Maroulitsa Profylienou, Antrianna Pollaki and Nikolaos Zografakis, 2011, "Tourists' Attitudes for Selecting Accommodation with Investments in Renewable Energy and Energy Saving Systems", Renewable and Sustainable Energy Reviews, 15, pp. 1335-1342. https://doi.org/10.1016/j.rser.2010.10.009

United Nations Environment Programme (UNEP) and International Council for Local Environmental Initiatives (ICLEI), 2003, Tourism and Local Agenda 21, The Role of Local Authorities in Sustainable Tourism, Paris and Freiburg: United Nations Environment Programme (UNEP) and International Council for Local Environmental Initiatives (ICLEI).

United Nations Environment Programme (UNEP) and The World Tourism Organization (UNWTO), 2012, Tourism in the Green Economy - Background Report, Madrid: The World Tourism Organization (UNWTO), https://www.eunwto.org/doi/pdf/10.18111/9789284414529 (accessed December 18, 2016).

Zografakis, Nikolas and Elli Sifaki, 2010, "Assessment of Public Acceptance and Willingness to Pay for Renewable Energy Sources in Crete", Renewable and Sustainable Energy Reviews, 14, pp. 1088-1095. https://doi.org/10.1016/j. rser.2009.11.009 